\title{
PENGARUH KUALITAS PELAYANAN TERHADAP KEPUASAN PELANGGAN PADA KANTOR POS SINDANGLAYA CIPANAS
}

Sirojudin $^{1 *}$, Desti Nurwidiawati ${ }^{2}$, Asrti Mailani ${ }^{3}$, Rizki Alyan $S^{4}$, Agus Irawan ${ }^{5}$, M. Yusuf Nurohman ${ }^{6}$, Sandi Aditya ${ }^{7}$

${ }^{1234567}$ Fakutas Ekonomi dan Bisnis Islam, Universitas Suryakancana *Corresponding Author e-mail: asirodj@gmail.com

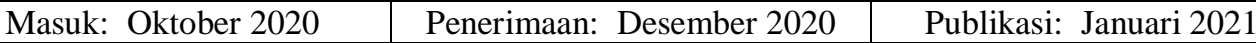

Tujuan penelitian ini adalah untuk mengetahui pengaruh kualitas pelayanan terhadap kepuasan pelanggan pada kantor pos Sindanglaya. Jenis penelitian ini adalah field research dengan pendekatan kuantitatif. Populasi dalam penelitian ini adalah seluruh pelanggan yang menggunakan jasa pelayanan pengiriman barang di kantor pos Sindanglaya Kecamatan Cipanas, Kabupaten Cianjur. Sampel yang diambil sebanyak 100 responden. Teknik pengumpulan data menggunakan kuesioner. Teknik analisis data menggunakan uji analisis regresi linier sederhana. Hasil penelitian ini menunjukkn bahwa variabel kualitas pelayanan memiliki t hitung yang bernilai positif sebesar 0,5688 dengan taraf signifikansi 0,000 diatas signifikansi $0,05(0,000<0,05)$. Dengan demikian $\mathrm{t}_{\text {hitung }} \mathrm{t}$ tabel $(5,688>$ 1,984), maka $\mathrm{H}_{0}$ ditolak dan $\mathrm{H}_{\mathrm{a}}$ diterima. Sehingga dapat dinyatakan bahwa Kualitas Pelayanan memiliki pengaruh signifikan terhadap Kepuasan Pelanggan pada PT. Pos Sindanglaya. Adapun persamaan analisis regresi linier sederhananya yaitu: $\hat{Y}=9,118+0,139 X$.

Kata Kunci: Kualitas Pelayanan, Kepuasan Pelanggan, Kantor Pos dan Regresi Linear Sederhana.

\section{ABSTRACT}

The purpose of this study was to determine the effect of service quality on customer satisfaction at the Sindanglaya post office. This type of research is field research with a quantitative approach. The population of this study were all customers of the Sindanglaya Post Office. The data collection technique used a questionnaire. The data analysis technique used simple linear regression analysis. The population in this study were all customers who used the delivery service at the Sindanglaya post office. Samples taken were 100 respondents. The results of this study indicate that the service quality variable has a positive $t$ count of 0.5688 with a significance level of 0.000 above the significance of $0.05(0.000<0.05)$. Thus $t$ count t table (5.688> 1.984), then HO is rejected and Ha is accepted. So it can be stated that Service Quality has a significant influence on Customer Satisfaction at PT. POS. Sindanglaya. Simple linear regression analysis $\hat{Y}=9,118+$ $0,139 X$.

Keywords: $\quad$ Service Quality, Customer Satisfaction, Post Office and Simple Linear Regression. 


\section{A. PENDAHULUAN}

Kualitas memiliki hubungan yang erat dengan kepuasan pelanggan. Kualitas memberikan suatu dorongan kepada pelanggan untuk menjalin ikatan hubungan yang kuat dengan perusahaan. Dalam jangka panjang, perusahaan dapat meningkatkan kepuasan pelanggan dimana perusahaan memaksimumkan pengalaman pelanggan yang menyenangkan dan meminimumkan pengalaman pelanggan yang kurang menyenangkan.

Setiap perusahaan dituntut untuk dapat memberikan kepuasan kepada pelanggannya dengan penawaran dan pelayanan yang optimal, mengingat perusahaan harus mampu mempertahankan posisinya di tengah persaingan bisnis yang ketat seperti sekarang ini. Wyckof dalam Arief "kualitas pelayanan merupakan tingkat keunggulan yang diharapkan dan pengedalian atas tingkat keunggulan tersebut untuk memenuhi keinginan pelanggan (Arief, 2010). Kualitas pelayanan itu juga harus memperhatikan tentang bukti fisik yaitu barang maupun pelayanan yang diberikan harus dalam kondisi yang baik, hal lainnya yaitu keandalan merupakan kemampuan untuk menghasilkan kinerja pelayanan yang dijanjikan secara akurat dan pasti”. Aspek jaminan meliputi pengetahuan dan rasa hormat para karyawan serta kemampuan pelayanan pada konsumen berarti adanya jaminan tersebut konsumen bisa merasa puas tentang pelayanan yang diberikan perusahaan. Empati juga harus dalam pelayanan yang berkualitas dikarenakan agar konsumen merasa puas terhadap pelayanan yang diberikan oleh perusahaan jasa. Hal-hal yang berkaitan tentang pelayanan yang berkualitas tersebut dapat meningkatkan kepuasan pelanggan itu dikarenakan hal yang dilakukan oleh perusahaan yang maksimal tentang pelayanan tersebut akan didapatkan oleh pelanggan sehingga nantinya dapat mempersepsikan bahwa pelanggan adalah raja sehingga mendapatkan pelayanan yang maksimal dan mendapatkan kepuasan pelanggan.

Kepuasan pelanggan merupakan respon pelanggan terhadap ketidak sesuaian antara tingkat kepentingan sebelumnya dengan kinerja aktual yang dirasakannya setelah pemakaian. Kepuasan pelanggan ditentukan oleh kualitas barang atau jasa yang ditawarkan, sehingga kualitas merupakan prioritas utama bagi perusahaan sebagai tolok ukur keunggulan bersaing (Elis Ratna Wulan \& Uus Ahmad Husaeni, 2015). 
Perusahaan yang gagal memuaskan pelayanannya akan menghadapi masalah yang kompleks. Umumnya pelanggan yang tidak puas akan menyampaikan pengalaman buruknya kepada orang lain dan bisa dibayangkan betapa besarnya kerugian dari kegagalan memuaskan pelanggan. Oleh karena itu, setiap perusahaan jasa wajib merencanakan, mengorganisasikan, mengimplementasikan, dan mengendalikan sistem kualitas sedemikian rupa, sehingga pelayanan dapat memuaskan para pelanggannya.

Kepuasan pelanggan dipengaruhi oleh kualitas pelayanan dimana terdapat lima dimensi. Menurut Agustyn, menunjukkan bahwa persepsi pelanggan terhadap kualitas pelayanan meliputi persepsi yang berhubungan dengan sarana fisik (Tangibles), kehandalan (Reliability), daya tanggap (Responsiveness), jaminan (Assurance) dan empati (Empathy).

PT POS Indonesia atau lebih dikenal dengan Kantor Pos adalah salah satu Badan Usaha yang bergerak di bidang jasa khususnya pengiriman surat menyurat. Sejarah mencatat keberadaan Pos Indonesia begitu panjang, Kantor Pos pertama didirikan di Batavia pelanggan dengan karyawan tidak seimbang, sehingga banyak pelanggan yang kecewa. Berikut data statistik jumlah pengunjung daribulan September-Oktober tahun 2020 :

Tabel 1

Data Statistik Pengunjung yang Menggunaka Jasa Pengiriman pada Kantor Pos Sindanglaya Bulan September-Oktober 2020

\begin{tabular}{ll}
\hline \multicolumn{1}{c}{ Bulan } & Jumlah Pengunjung \\
\hline September & 5.399 pengunjung \\
\hline Oktober & 5.190 pengunjung \\
\hline \multicolumn{2}{c}{ Sumber: Kantor Pos Sindanglaya }
\end{tabular}

Berdasarkan tabel di atas dapat dilihat bahwa jumlah pelanggan yang datang ke Kantor Pos Sindanglaya mengalami penurunan dari bulan SeptemberOktober. Hal ini juga berarti bahwa ada penurunan penggunaan jasa Kantor Pos Sindanglaya,dapat dilihat bahwa pada bulan September sejumlah 5.399 pelanggan, dan pada bulan Oktober sejumlah 5.190 pelanggan.

Dari latar belakang diatas dapat diidentifikasi masalah yang akan diteliti ialah barang yang dikirim tidak sesuai dengan jadwal yang ditetapkan atau sering terlambat. Berdasarkan identifikasi masalah diatas, maka menjadi batasan masalah dalam penelitian ini adalah Seberapa besar pengaruh kualitas pelayanan terhadap 
kepuasan Pelanggan yang menggunakan jasa pengiriman barang pada Kantor Pos Sindanglaya. Maka yang menjadi rumusan masalah dalam penelitian ini adalah Apakah ada pengaruh kualitas pelayan terhadap kepuasan pelanggan pada Kantor Pos Sindanglaya. Sedangkan, tujuan diadakan penelitian ini adalah Untuk mengetahui pengaruh kualitas pelayanan terhadap kepuasan pelanggan pada Kantor Pos Sindanglaya.

\section{B. METODELOGI PENELITIAN}

Penelitian yang penulis lakukan adalah penelitian lapangan (field research) yaitu penelitian yang dilakukan dengan turun langsung ke lapangan untuk memperoleh data-data yang relevan dengan penelitian yang dilakukan. Jenis penelitian yang penulis lakukan adalah penelitian Deskriptif kuantitatif yaitu penelitian yang melihat suatu realitas sebagai hal yang tunggal, teramati dan dapat dipragmentasikan sehingga dari masalah yang ada itu dapat memprediksi suatu masalah berdasarkan sejumlah variabel prediktor (Abdul Halim Hanafi, 2011).

Melalui penelitian ini dapat menganalisis seberapa besar pengaruh kualitas pelayanan terhadap kepuasan pelanggan pada PT Pos Sindanglaya. Kegiatan penelitian yang penulis lakukan mulai dari bulan September 2020-Oktober 2020. Penelitian yang penulis dilakukan pada Kantor Pos Sindanglaya Cipanas Kabupaten Cianjur Jawa Barat.

Populasi dalam penelitian ini adalah seluruh pengunjung kantor POS Sindanglaya. Berikut jumlah pengunjung kantor Pos Sindanglaya selama bulan September-Oktober 2020.

Tabel 2

Data Statistik Pengunjung yang menggunaka jasa pengiriman pada Kantor Pos Sindanglaya Bulan September-Oktober 2020

\begin{tabular}{|c|c|}
\hline Bulan & Jumlah Pengunjung \\
\hline September & 5.399 \\
\hline Oktober & 5.190 \\
\hline Total & 10.589 \\
\hline
\end{tabular}

Sampel dalam penelitian ini ditentukan berdasarkan rumus Slovin dikutip oleh (Husein Umar, 2010) adalah sebagai berikut:

$$
\mathrm{n}=\frac{\mathrm{N}}{1+\mathrm{N}_{2}}
$$




$$
\begin{aligned}
\mathrm{n} & =\frac{10.589}{1+10.589(0.10)^{2}} \\
\mathrm{n} & =99,06 \\
\mathrm{n} & =100 \text { sampel }
\end{aligned}
$$

Berdasakan perhitungan rumus diatas, maka jumlah sampel dalam penelitian ini berjumlah 100 orang responden.

Teknik pengumpulan data yang digunakan dalam penelitian ini adalah dengan menggunakan angket, yang secara langsung diberikan kepada responden tanpa perantara. Angket atau kuesioner tersebut disusun dengan menggunakan 5 (lima) alternatif jawaban, yaitu: SS (Sangat Setuju), S (Setuju), RR (Ragu-Ragu), TS (Tidak Setuju), STS (Sangat Tidak Setuju). Penskoran untuk masing-masing pernyataan dapat dilihat pada tabel berikut:

Tabel 3

Skors Penilaian Kuesioner

\begin{tabular}{lc}
\hline \multicolumn{1}{c}{ Pilihan Jawaban } & Skors \\
\hline Sangat Setuju (SS) & 5 \\
\hline Setuju (S) & 4 \\
\hline Ragu-Ragu (RR) & 3 \\
\hline Tidak Setuju (TS) & 2 \\
\hline Sangat Tidak Setuju (STS) & 1 \\
\hline \multicolumn{2}{c}{ Sumber: Sugiyono (2014) }
\end{tabular}

Kuesioner menurut (Sugiyono, 2014) merupakan teknik pengumpulan data dimana partisipan/responden mengisi pertanyaan atau pernyataan kemudian setelah diisi dengan lengkap mengembalikan kepada peneliti. Metode ini akan digunakan peneliti untuk memperoleh data mengenai pengaruh kualitas pelayanan terhadap kepuasan pelanggan pada kantor pos Sindanglaya.

\section{PEMBAHASAN DAN HASIL PENELITIAN}

\section{Kualitas Pelayanan}

Wyckof dalam (Arief, 2010) "kualitas pelayanan merupakan tingkat keunggulan yang diharapkan dan pengedalian atas tingkat keunggulan tersebut untuk memenuhi keinginan pelanggan. Kualitas pelayanan itu juga harus memperhatikan tentang bukti fisik yaitu barang maupun pelayanan yang diberikan harus dalam kondisi yang baik, hal lainnya yaitu keandalan merupakan kemampuan untuk menghasilkan kinerja pelayanan yang dijanjikan secara akurat 
dan pasti". Aspek jaminan meliputi pengetahuan dan rasa hormat para karyawan serta kemampuan pelayanan pada konsumen berarti adanya jaminan tersebut konsumen bisa merasa puas tentang pelayanan yang diberikan perusahaan. Empati juga harus dalam pelayanan yang berkualitas dikarenakan agar konsumen merasa puas terhadap pelayanan yang diberikan oleh perusahaan jasa. Hal-hal yang berkaitan tentang pelayanan yang berkualitas tersebut dapat meningkatkan kepuasan pelanggan itu dikarenakan hal yang dilakukan oleh perusahaan yang maksimal tentang pelayanan tersebut akan didapatkan oleh pelanggan sehingga nantinya dapat mempersepsikan bahwa pelanggan adalah raja sehingga mendapatkan pelayanan yang maksimal dan mendapatkan kepuasan pelanggan.

Menurut (Fandy Tjiptono, 2010) "kepuasan atau ketidakpuasan pelanggan adalah respons pelanggan terhadap evolusi ketidaksesuaian (discinfirmation) yang dirasakan antara harapan sebelumnya dan kinerja aktual produk yang dirasakan pada persaingan yang semakin ketat ini”. Kepuasan pelanggan menjadi poin penting dalam perusahaan jasa karena apabila kepuasan pelanggan didapatkan, konsumen tersebut akan menggunakan kembali perusahaan jasa tersebut, selain itu hal lainnya dapat menjadikan strategi word of mouth yaitu menyebarkan kepuasan sesama pelanggan sehingga poin tersebut menjadikan keuntungan tersendiri bagi perusahaan jasa tersebut.

Menurut American Society For Quality Control, kualitas adalah keseluruhan dari ciri-ciri dan karakteristik-karakteristik dari suatu produk atau jasa dalam hal kemampuannya untuk memenuhi kebutuhan- kebutuhan yang telah ditentukan atau bersifat laten, dan dengan kata lain kualitas suatu poduk/jasa adalah sejauh mana produk/jasa memnuhi spesifikasi-spesifikasinya (Ririn Triratna Sari \& Mastuti Aksa, 2011).

Sedangkan menurut (Philip Kotler \& Kevin Lane Keller, 2011), kualitas didefinisikan sebagai keseluruhan ciri serta sifat barang dan jasa yang berpengaruh pada kemampuan memenuhi kebutuhan yang dinyatakan maupun yang tersirat. Dari tiga pendapat diatas dapat disimpulkan bahwa kualitas merupakan ciri-ciri atau karakteristik dari suatu produk atau jasa dalam hal kemampuannya untuk memenuhi kebutuhan-kebutuhan yang telah ditentukan.

Dalam hal pelayanan sering kali terkait unsur jasa. Sehingga pelayanan sering pula disebut sebagai jasa. Sejumlah ahli tentang telah berupaya untuk 
merumuskan definisi jasa konklusif namun hingga sekarang belum ada satupun definisi yang diterima secara bulat. Kualitas pelayanan merupakan tingkat kesempurnaan yang diharapkan dan pengendalian atas kesempurnaan tersebut untuk memenuhi keinginan pelanggan. Dengan kata lain, terdapat dua faktor utama yang mempengaruhi kualitas jasa yaitu jasa yang diharapkan dan jasa yang dipersepsikan. Implikasinya, baik buruk kualitas jasa tergantung pada kemampuan penyedia jasa dalam memenuhi harapan pelanggan secara konsisten (Affandi et al., 2017).

Dalam rangka menciptakan kepuasan pelanggan, produk yang ditawarkan harus berkualitas. Istilah kualitas sendiri mengandung berbagai macam penafsiran, secara sederhana kualitas dapat diartikan sebagai produk yang bebas cacat. Kualitas juga merupakan komponen pemasaran yang langsung mempengaruhi kepuasan konsumen terhadap suatu produk yang dikonsumsinya. Atas dasar ini, maka dengan kualitas produk yang baik diharapkan dapat memberikan kepuasan yang besar terhadap para konsumennya. Menurut davis "kualitas merupakan suatu kondisi dinamis yang berhubungan dengan produk, jasa, manusia, proses, dan lingkungan yang memenuhi atau melebihi harapan” (Tjiptono \& Diana, 2010).

Dalam konsep pemasaran, kualitas diukur dari sudut padang dan anggapan pembeli terhadap kualitas itu sendiri. Kualitas adalah totalitas fitur dan karakteristik dari suatu produk atau jasa yang bergatung pada kemampuannya untuk memuaskan kebutuhan yang dinyatakan atau tersirat (Philip Kotler \& Kevin Lane Keller, 2011). Dengan kualitas yang baik akan menyebebkan kepuasan konsumen semakin besar dan pada akhirnya akan meningkatkan penjualan dan laba bagi perusahaan.

Parasuraman dalam (Tjiptono \& Diana, 2010) berhasil mengidentifikasi lima kelompok karakteristik yang digunakan oleh para pelanggan dalam mengevaluasi kualitas pelayanan:

a. Tangibles, atau bukti fisik yaitu kemampuan perusahaan dalam menunjukkaneksistensinya kepada pihak eksternal. Yang dimaksud bahwa penampilan dan kemampuan sarana dan prasarana fisik perusahaan dan keadaan lingkungan sekitarnya adalah bukti nyata dan pelayanan yang diberikan;

b. Reliability, atau keandalan yaitu kemampuan perusahaan untuk 
memberikan pelayanan sesuai yang dijanjikan secara akurat dan terpercaya;

c. Responsiveness, atau ketanggapan yaitu suatu kemauan untuk membantu dan memberikan pelayanan yang cepat dan tepat kepada pelanggan, dengan penyampaian informasi yang jelas;

d. Assurance, atau jaminan dan kepastian yaitu pengetahuan, kesopansantunan, dan kemampuan para pegawai perusahaan untuk menumbuhkan rasa percaya para pelanggan kepada perusahaan. Terdiri dari beberapa komponen antara lain komunikasi, kredibilitas, keamanan, kompetensi dan sopan santun;

e. Empathy, yaitu memberikan perhatian yang tulus dan bersifat individual atau pribadi yang diberikan kepada para pelanggan dengan berupaya memahami keinginan pelanggan. Sebagai contoh perusahaan harus mengetahui keinginan pelanggan secara spesifik dari bentuk fisik produk atau jasa sampai pendistribusian yang tepat.

\section{Pengukuran Kualitas}

Kualitas pelayanan sangat erat hubungannya dengan kepuasan pelanggan.

Kemajuan sebuah perusahaan salah satunya dipengaruhi oleh kemampuan perusahaan dalam melayani konsumennya. Pelayanan yang perusahaan berikan harus memperhatikan kualitas standar yang diberikan kepada pelanggan bahkan harus melebihi efektasi yang diharapkan oleh pelanggan sehingga kepuasan pelanggan dapat diperoleh dengan mudah oleh perusahaan, karena itu dapat membuat para pelanggan bertahan menggunakan jasa perusahaan (Rohaeni \& Marwa, 2018).

Menurut Garvin dalam Tjiptono pendekatan kualitas meliputi:

a. Trancendental approach, yaitu kualitas dipandang sebagai innateexcellence berarti kualitas itu dapat dirasakan, diketahui, tetapi sulit didefinisikan dan dioperasionalisasikan;

b. Product-based approach, artinya kualitas merupakan karakteristik atau atribut yang dapat dikualifikasi dan dapat diukur. Perbedaan dalam kualitas mencerminkan perbedaan dalam jumlah beberapa unsur atribut yang dimiliki produk; 
c. User-based approach, yang berdasarkan pada pemikiran bahwa kualitas tergantung pada orang yang memandangnya, sehingga produk yang paling memuaskan preferensi seseorang merupakan produk yang berkualitas tinggi;

d. Manufacturing-based approach, dimana kualitas didefinisikan sebagai kesesuaian dengan persyaratan. Pendekatan ini berfokus pada penyesuaian spesifikasi yang dikembangkan secara internal, yang sering kali didorong oleh tujuan peningkatan produktifitas dan penekanan biaya. Jadi yang menentukan kualitas adalah standar yang ditetapkan oleh perusahaan, bukan konsumen yang menggunakannya;

e. Value-based approach, yang memandang kualitas dari segi nilai dan harga. Akibatnya kualitas bersifat relatif, sehingga produk yang memiliki kualitas paling tinggi belum tentu merupakan produk yang paling bernilai.

\section{Kepuasan Pelanggan}

Oliver dalam Barnes "menyatakan kepuasan adalah tanggapan pelanggan atas terpenuhinya kebutuhan yang berarti bahwa penilaian pelanggan atas barang atau jasa memberikan tingkat kenyamanan yang terkait dengan pemenuhan suatu kebutuhan, termasuk pemenuhan kebutuhan yang tidak sesuai harapan atau pemenuhan yang melebihi harapan pelanggan". Sehingga dapat disimpulkan bahwa kepuasan pelanggan merupakan respon terhadap hasil yang dirasakan oleh pelanggan atas kesesuaian harapan terkait dengan pemenuhan kebutuhan pelanggan.

Kepuasan menunjukkan bahwa secara simultan kualitas pelayanan yang terdiri dari bukti fisik, keandalan, daya tanggap, jaminan dan empati berpengaruh signifikan terhadap kepuasan pelanggan. Hal ini berarti semakin baik kualitas pelayanan yang dirasakan oleh pelanggan maka semakin tinggi pula kepuasan yang mereka sarankan (Made et al., 2015).

Kepuasan pelanggan telah menjadi konsep sentral dalam wacana bisnis dan manajemen. Pelanggan merupakan fokus utama pembahasan mengenai kepuasan dan kualitas pelayanan. Oleh karena itu, pelanggan memegang peranan cukup penting dalam mengukur kepuasan terhadap produk maupun pelayanan yang diberikan perusahaan. Sedangkan menurut Sumarwan, kepuasan pelanggan 
merupakan dampak dari perbandingan antara harapan pelanggan sebelum pembelian dengan yang sesungguhnya diperoleh pelanggan dari produk yang dibeli tersebut. Menurut (Philip Kotler \& Kevin Lane Keller, 2011), kepuasan adalah tingkat perasaan seseorang setelah membandingkan kinerja atau hasil yang dia rasakan dibandingkan dengan harapannya.

Kepuasan konsumen terhadap perusahaan jasa diartikan sebagai suatu keadaan dimana harapan konsumen terhadap suatu pelayanan sesuai dengan kenyataan yang diterima tentang pelayanan yang diberikan kepada konsumen. Jika pelayanan suatu perusahaan jasa tersebut jauh dibawah harapan konsumen maka konsumen akan kecewa. Sebaliknya, jika layanan yang diberikan memenuhi harapan konsumen, maka konsumen akan senang. Harapan konsumen dapat diketahui dari pengalaman mereka sendiri saat menggunakan pelayanan suatu perusahaan jasa, omongan orang lain dan informasi iklan (Panjaitan \& Yuliati, 2016).

Kepuasan pelanggan yang ditinjau dari sisi pelanggan yaitu mengenai apa yang telah dirasakan pelanggan atas pelayanan yang telah diberikan dibandingkan dengan apa yang mereka inginkan. Kepuasan adalah tingkat perasaan seseorang setelah membandingkan kinerja atau hasil yang dia rasakan dibandingkan dengan harapannya. Sedangkan ketidakpuasan timbul apabila hasil tidak memenuhi harapan. Kepuasan pelanggan terhadap suatu produk ataupun jasa, sebenarnya sesuatu yang sulit untuk didapat jika perusahaan jasa atau industri tersebut tidak benar-benar mengerti apa yang diharapkan oleh konsumennya (Lubis \& Andayani, 2018).

a. Dari definisi di atas dapat ditarik kesimpulan bahwa kepuasan pelanggan yang ditinjau dari sisi pelanggan yaitu mengenai apa yang telah dirasakan pelanggan atas pelayanan yang telah diberikan dibandingkan dengan apa yang mereka inginkan. Ada lima dimensi yang mempengaruhi kepuasan pelanggan, yaitu:

b. Kecepatan pelayanan, dilihat dari kecepatan memberikan tanggapan, penyelesaian masalah dan pengambilan keputusan;

c. Keramahan karyawan, dilihat dari perilaku sopan santun, tutur kata, penampilan yang menarik;

d. Pengetahuan karyawan, mampu menjelaskan dengan memuaskan, 
memberikan advokasi dan alternative solusi;

e. Jumlah pelayanan yang tersedia, yaitu rasio-rasio tempat pelayanan dengan yang dilayani atau rasio jumlah aparat dengan yang dilayani;

f. Tampilan formalitas, dilihat dari ketersediaan sarana pendukung, kerapihan dan kenyamanan tempat kerja.

Menurut (Fandy Tjiptono, 2010) Adanya kepuasan dapat memberikan beberapa manfaat, diantaranya adalah:

a. Hubungan antara perusahaan dan para pelanggan menjadi harmonis;

b. Memberikan dasar yang baik bagi pemakaian ulang;

c. Dapat mendorong terciptanya kepuasan pelanggan;

d. Laba yang diperoleh dapat meningkat.

Menurut (Fandy Tjiptono, 2010) ada empat (4) metode pengukuran kepuasan pelanggan yaitu sebagai berikut:

a. Sistem Keluhan dan Saran

Media yang digunakan bisa berupa kotak saran yang diletakkan di tempattempat strategis, kartu komentar, saluran telepon khusus bebas pulsa, website, dan lain-lain.

b. Ghost Shopping

Salah satu metode untuk memperoleh gambaran mengenai kepuasan pelanggan adalah dengan mempekerjakan beberapa orang ghost shoppers untuk berperan sebagai pelanggan potensial jasa perusahaan dan pesaing.

c. Lost Customer Analysis

Perusahaan sebaiknya menghubungi para pelanggan yang telah berhenti membeli atau yang telah beralih pemasok, agar dapat memahami mengapa hal itu terjadi dan supaya dapat mengambil kebijakan perbaikan / penyempurnaan selanjutnya.

d. Survei Kepuasan Pelanggan

Melalui survei, perusahaan akan memperoleh tanggapan dan umpan balik langsung dari pelanggan dan juga memberikan sinyal positif bahwa perusahaan menaruh perhatian terhadap mereka.

\section{Kepuasan Pelanggan Terhadap Kualitas Jasa}

Menurut Valarie A. Zeithaml \& Mary Bo Jitnes dalam bukunya services 
marketing, kualitas jasa adalah tingkat keunggulan yang diharapkan dan pengendalian atas tingkat keunggulan tersebut untuk memenuhi keinginan pelanggan. Dengan demikian, ada dua faktor utama yang mempengaruhi kualitas jasa, yaitu Expected Service dan Perceived Service. Apabila jasa yang diterima atau dirasakan (Perceived Service) sesuai dengan apa yang diharapkan, maka kualitas jasa dipersepsikan baik dan memuaskan.

Jika jasa yang diterima melampui harapan pelanggan, maka kualitasa jasa dipersepsikaan sebagai kualitas yang ideal. Sebaliknya jika jasa yang diterima lebih rendah dari pada yang diharapkan, maka kualitas jasa yang dipersepsikan buruk. Maka baik tidaknya kualitas jasa tergantung pada penyedia jasa dalam memenuhi harapan pelanggannya secara konsisten. Menurut Parasuraman dalam bukunya marketing services kualitas total suatu jasa terdiri dari tiga komponen utama, yaitu:

a. Tecbnical Quality yaitu komponen yang berkaitan dengn kualitas output jasa yang diterima pelanggan;

b. Functional Quality yaitu komponen yang berkaitan dengan kualitas cara penyampaian suatu jasa;

c. Corporate Image yaitu profil, reputasi, citra umum, dan daya tarik khusus suatu perusahaan.

Adapun hasil dari penelitian ini maka diperoleh data sebagai berikut:

Tabel 4

Kualitas pelayanan

\begin{tabular}{clcc}
\hline \multicolumn{4}{c}{ Kualitas pelayanan } \\
No & \multicolumn{1}{c}{ Pilihan Jawaban } & $\begin{array}{c}\text { Frekuensi } \\
\text { Jawaban }\end{array}$ & Persentase \\
\hline 1 & Sangat Baik (SB) & 13 & $13 \%$ \\
\hline 2 & Baik (B) & 62 & $62 \%$ \\
\hline 3 & Cukup Baik (CB) & 23 & $23 \%$ \\
\hline 4 & Tidak Baik (TB) & 2 & $2 \%$ \\
\hline 5 & Sangat Tidak Baik (STB) & 0 & $0 \%$ \\
\hline \multicolumn{2}{r}{ Jumlah } & $\mathbf{1 0 0}$ & $\mathbf{1 0 0 \%}$ \\
\hline
\end{tabular}

Berdasarkan tabel diatas dapat dilihat bahwa persentase untuk jawaban Sangat Baik (SB) adalah sebesar 13\%, Baik (B) adalah 62\%, Cukup Baik (CB) 23\%, Tidak Baik (TB) 2\% dan untuk Sangat Tidak Baik (STB) sebesar ) 0\%.

Tabel 5

Kepuasan Pelanggan

No. Pilihan Jawaban $\quad \begin{gathered}\text { Frekuensi } \\ \text { Jawaban }\end{gathered}$ Persentase

Copyright (C 2019, El-Ecosy: Jurnal Ekonomi dan Keuangan Islam

Fakultas Ekonomi dan Bisnis Islam Universitas Suryakancana 


\begin{tabular}{clcc}
\hline 1 & Sangat Puas (SP) & 13 & $13 \%$ \\
\hline 2 & Puas (P) & 62 & $62 \%$ \\
\hline 3 & Cukup Puas (CP) & 24 & $24 \%$ \\
\hline 4 & Tidak Puas (TP) & 1 & $1 \%$ \\
\hline 5 & Sangat Tidak Puas (STP) & 0 & $0 \%$ \\
\hline & Jumlah & $\mathbf{1 0 0}$ & $\mathbf{1 0 0 \%}$ \\
\hline
\end{tabular}

Berdasarkan tabel diatas dapat dilihat bahwa persentase untuk jawaban Sangat Puas (SP) adalah sebesar 13\%, Puas (P) adalah 62\%, Cukup Puas (CP) 24\%, Tidak Puas (TP) 1\% dan untuk Sangat Tidak Puas (STP) sebesar) $0 \%$.

Tabel 6

Hasil Analisis Linear Sederhana Coefficients $^{\mathrm{a}}$

\begin{tabular}{|c|c|c|c|c|c|c|}
\hline & \multirow[t]{2}{*}{ Model } & \multicolumn{2}{|c|}{$\begin{array}{c}\text { Unstandardized } \\
\text { Coefficients }\end{array}$} & $\begin{array}{r}\text { Standardized } \\
\text { Coefficients }\end{array}$ & \multirow[t]{2}{*}{$\mathrm{T}$} & \multirow[t]{2}{*}{ Sig. } \\
\hline & & $\mathrm{B}$ & Std. Error & Beta & & \\
\hline \multirow[t]{2}{*}{1} & (Constant) & 9.118 & 2.295 & & 3.973 & .000 \\
\hline & Kualitas Pelayanan & .139 & .024 & .49 & 5.688 & .000 \\
\hline
\end{tabular}

a. Dependent Variable: Kepuasan Pelanggan

Sumber :data diolah menggunakn SPSS 22

Dari tabel analisis regresi linier sederhana di atas maka dapat dibuatkan ke dalam persamaan sebagai berikut:

$$
\begin{aligned}
& \hat{Y}=a+b X \\
& \hat{Y}=9,118+0,139 X
\end{aligned}
$$

Interprestasi persamaan diatas :

1. Konstanta 9,118 menunjukkan tanpa adapun pengaruh variabel bebas, yaitu kualitas pelayanan (X) maka kepuasan pelanggan (Y) nilainya sebesar 9,118;

2. Variabel kualitas pelayanan (X), memiliki koefisien regresi positif sebesar 0,139 Jika variabel kualitas pelayanan meningkat satu satuan, maka kepuasan pelanggan (Y) akan mengalami kenaikan sebesar 0,139 dengan anggapan variabel bebas lainnya tetap.

Berdasarkan tabel 1.6 diatas dapat diketahui variabel kualitas pelayanan memiliki t hitung yang bernilai positif sebesar 0,5688 dengan taraf signifikansi 0,000 diatas signifikansi $0,05(0,000<0,05)$. Dengan demikian $t_{\text {hitung }} t_{\text {tabel }}(5,688$ > 1,984), maka $\mathrm{H}_{0}$ ditolak dan $\mathrm{H}_{\mathrm{a}}$ diterima. Sehingga dapat dinyatakan bahwa Kualitas Pelayanan memiliki pengaruh signifikan terhadap Kepuasan Pelanggan pada PT. Pos Sindanglaya.

Secara umum penelitian ini menunjukkan bahwa pelayanan yang diberikan 
oleh Pos Sindanglaya belum maksimal, hal ini dapat dilihat dari hasil jawaban responden melalui angket yang disebarkan ke pelanggan. Hal ini dikarenakan beberapa faktor penghambat. Adapun analisis data yang telah diuraikan sebelumnya dapat persamaan regresi sederhana $\hat{\mathrm{Y}}=\mathrm{a}+\mathrm{bX}$, dimana nilai $\mathrm{a}=$ 9,118 dan nilai $\mathrm{b}=0,139$ dan jika dimasukkan kedalam persamaan regresi sederhana menjadi $\hat{Y}=9,118+0,139 X$. jadi interprestasinya adalah peningkatan kualitas pelayanan akan diikuti dengan peningkatan kepuasan pelanggan, berdasarkan analisis-analisis tersebut, maka hipotesis yang penulis ajukan yaitu terdapat pengaruh positif antara variable kualtias pelayanan $(\mathrm{X})$ dengan variable kepuasan pelanggan (Y) pada pos Sindanglaya dapat diterima serta terbukti kebenarannya. Dalam pembahasan mengenai hasil analisis yang telah dilakukan. analisis tersebut adalah sebagai berikut: Dari pengolahan data SPSS 22 didapat t hitung sebesar 5,688 dan signifikasi sebesar 0,000. Dibandingkan dengan $\mathrm{t}$ tabel sebesar 1,661, maka $\mathrm{t}$ hitung lebih besar dari $\mathrm{t}$ tabel dan nilai signifikansi lebih kecil dari 0,05. Maka dapat disimpulkan kualitas pelayanan berpengaruh terhadap kepuasan pelanggan. Semakin baik kualitas pelayanan yang diberikan kepada pelanggan, maka semakin tinggi pula tingkat kepuasan yang diterima pelanggan. Kepercayaan pelanggan akan semakin tinggi apabila pelanggan mendapatkan pelayanan yang baik dan merasa terpuaskan akan pelayanan tersebut.

Dari hasil penelitian ini membuktikan teori yang dikemukan oleh Wyckof, kualitas pelayanan adalah sebuah tingkat keunggulan yang diharapkan, serta berkaitan dengan hal itu adalah tindakan pengendalian atas tingkat keunggulan tersebut untuk memenuhi harapan konsumen. Wyckof melihat kualitas pelayanan tidak dipandang berdasarkan sudut pandang produsen melainkan dari persepsi orang yang menerima pelayanan. Hal ini karena konsumen yang merasakan dan mengkonsumsi pelayanan yang diberikan tersebut, sehingga konsumen mampu menilai dan menentukan kualitas pelayanan. Dengan demikian maka kualitas pelayanan yang baik maupun buruk tergantung pada konsistensi kemampuan produsen dalam memenuhi harapan para konsumennya.

Semakin baik kualitas pelayanan yang diberikan kepada pelanggan, maka semakain tinggi pula tingkat kepuasan yang diterima pelanggan/ masyarakat. Kepercayaan pelanggan akan semakain tinggi apabila pelanggan mendapatkan 
pelayanan yang baik dan merasa terpuaskan akan pelayaanan yang diberikan tersebut. Ini berarti, bila jasa atau layanan diterima sesuai dengan yang diharapkan maka kualitas jasa atau pelayanan dipersepsikan baik dan memuaskan, sebaliknya bila jasa atau layanan yang diterima lebih rendah dari yang diharapkan, maka kualitas jasa atau layanan dipersepsikan buruk. Jadi kepuasan pelanggan dapat tercipta apabila kualias peyanan dapat diterapkan sesuai ketentuan dan peraturan yang berlaku. Sehingga kualitas pelayanan mempunyai pengaruh terhadap kepuasan pelanggan.

\section{KESIMPULAN}

Berdasarkan hasil penelitian yang telah penulis lakukan pada Kantor Pos Sindanglaya sebagaimana yang telah dijelaskan dalam hasil sebelumnya dapat diambil kesimpulan yaitu semakin tinggi tingkat kualitas pelayanan maka akan semakin tinggi pula tingkat kepuasan pelanggan, begitu pula sebaliknya apabila rendah tingkat kualitas pelayanan, maka akan rendah pula tingkat kepuasan pelanggan. Hal yang mempengaruhi tingkat kepuasan pelanggan adalah kualitas pelayanan. Untuk menciptakan kepuasan pelanggan maka sebuah perusahaan harus memberikan pelayanan yang maksimal terhadap pelanggannya agar tujuan perusahaan dapat tercapai. Jadi kepuasan pelanggan dapat terlaksana apabila kualitas pelayanan dapat diterapkan sesuai ketentuan dan peraturan yang berlaku. Sehingga kualitaspelayanan mempunyai pengaruh terhadap kepuasan pelanggan.

\section{REFERENSI}

Abdul Halim Hanafi. (2011). Metode Penelitian Bahasa: untuk Penelitian Tesis dan Disertasi. Diadit Media.

Affandi, H., Zaki, M., Magister, M., Sipil, T., Teknik, F., Kuala, U. S., Sipil, M. T., Teknik, F., Kuala, U. S., Sipil, J. T., Teknik, F., \& Kuala, U. S. (2017). Pengaruh Kualitas Pelayanan Terhadap Kepuasan Pelanggan Pada Perusahaan Daerah Air Minum (Pdam) Tirta Mon Pase Kabupaten Aceh Utara. Jurnal Teknik Sipil, 6(3), 297-308.

Arief. (2010). Pemasaran Jasa dan Kualitas Jasa. Bayumedia.

Elis Ratna Wulan \& Uus Ahmad Husaeni. (2015). Analysis of the Variables that Affect Bookstore Customer Satisfaction. International Journal of Nusantara Islam, 3(2), 27-36. https://doi.org/10.15575/ijni.v3i2.484

Fandy Tjiptono. (2010). Manajemen Jasa. Andi.

Husein Umar. (2010). Riset Pemasaran dan Perilaku Konsumen. Gramedia Pustaka Utama.

Lubis, A. S., \& Andayani, N. R. (2018). Pengaruh Kualitas Pelayanan (Service 
Quality) Terhadap Kepuasan Pelanggan Pt. Sucofindo Batam. Journal of Applied Business Administration, 1(2), 232-243. https://doi.org/10.30871/jaba.v1i2.619

Made, N., Sulistyawati, A., \& Seminari, N. K. (2015). Pengaruh Kualitas Pelayanan Terhadap Kepuasan Pelanggan Restoran Indus Ubud Gianyar. 4(8), 2318-2332.

Panjaitan, J. E., \& Yuliati, A. L. (2016). Pengaruh Kualitas Pelayanan Terhadap Kepuasan Pelanggan Pada JNE Cabang Bandung. DeReMa (Development Research of Management): Jurnal Manajemen, 11(2), 265. https://doi.org/10.19166/derema.v11i2.197

Philip Kotler \& Kevin Lane Keller. (2011). Manajemen Pemasaran (12th ed.).

Ririn Triratna Sari \& Mastuti Aksa. (2011). Manajemen Pemasaran Jasa. Ghalia Indonesia.

Rohaeni \& Marwa, N. (2018). Kualitas Pelayanan terhadap Kepuasan Pelanggan. Jurnal Ecodemica, 20(2), 241-258.

Sugiyono. (2014). Metode Penelitian Manajemen. Alphabeta.

Tjiptono \& Diana. (2010). Strategi Pemasaran (2nd ed.). Andi. 